\title{
Pleiotrophin Suppression of Receptor Protein Tyrosine Phosphatase- $\beta / \zeta$ Maintains the Self-Renewal Competence of Fetal Human Oligodendrocyte Progenitor Cells
}

\author{
Crystal R. McClain, ${ }^{1,3}$ Fraser J. Sim, ${ }^{1,3}$ and Steven A. Goldman ${ }^{1,2,3}$ \\ Departments of ${ }^{1}$ Neurology and ${ }^{2}$ Neurosurgery and ${ }^{3}$ Center for Translational Neuromedicine, University of Rochester Medical Center, Rochester, New York \\ 14642
}

\begin{abstract}
Oligodendrocyte progenitor cells (OPCs) persist in human white matter, yet the mechanisms by which they are maintained in an undifferentiated state are unknown. Human OPCs differentially express protein tyrosine phosphatase receptor $\beta / \zeta$ (PTPRZ1) and its inhibitory ligand, pleiotrophin, suggesting the maintenance of an autocrine loop by which PTPRZ1 activity is tonically suppressed. PTPRZ1 constitutively promotes the tyrosine dephosphorylation of $\beta$-catenin and, thus, $\beta$-catenin participation in T cell factor (TCF)-mediated transcription. Using CD140a/PDGFR $\alpha$-based fluorescence-activated cell sorting to isolate fetal OPCs from the fetal brain at gestational ages 16-22 weeks, we asked whether pleiotrophin modulated the expansion of OPCs and, if so, whether this was effected through the serial engagement of PTPRZ1 and $\beta$-catenin-dependent signals, such as TCF-mediated transcription. Lentiviral shRNAiknockdown of PTPRZ1 induced TCF-mediated transcription and substantially augmented GSK3 $\beta$ inhibition-induced TCF-reporter luciferase expression, suggesting dual regulation of $\beta$-catenin and the importance of PTPRZ1 as a tonic brake upon TCF-dependent transcription. Pharmacological inhibition of GSK $3 \beta$ triggered substrate detachment and initiated sphere formation, yet had no effect on either proliferation or net cell number. In contrast, pleiotrophin strongly potentiated the proliferation of CD140a ${ }^{+}$-sorted OPCs, as did PTPRZ1 knockdown, which significantly increased the total number of population doublings exhibited by OPCs before mitotic senescence. These observations suggest that pleiotrophin inhibition of PTPRZ1 contributes to the homeostatic self-renewal of OPCs and that this process is mediated by the tonic activation of $\beta$-catenin/TCF-dependent transcription.
\end{abstract}

\section{Introduction}

Oligodendrocyte progenitor cells (OPCs) of the human white matter persist throughout adulthood and are capable of producing myelinogenic oligodendrocytes (Roy et al., 1999; Scolding et al., 1999; Windrem et al., 2002, 2004, 2008; Sim et al., 2011). Nonetheless, the mechanisms by which these cells are maintained in the self-renewing progenitor state are largely unknown (Franklin and ffrench-Constant, 2008). Both adult and fetal human OPCs express the receptor protein tyrosine phosphatase- $\beta / \zeta$ (PTPRZ1) and its inhibitory ligand pleiotrophin (Sim et al., 2006, 2011), suggesting the persistence of an autocrine loop by which PTPRZ1 is tonically regulated. PTPRZ1 has been reported to regulate the tyrosine dephosphorylation of the key Wnt pathway

\footnotetext{
Received March 16, 2012; revised July 9, 2012; accepted Aug. 12, 2012.

Author contributions: C.R.M., F.J.S., and S.A.G. designed research; C.R.M. performed research; F.J.S. contributed unpublished reagents/analytic tools; C.R.M., F.J.S., and S.A.G. analyzed data; C.R.M. and S.A.G. wrote the paper.

This work was supported by NINDS Grants P01NS050315 and R01NS039559 and NRSA Grant F31NS070441, the Department of Defense Congressionally Directed Medical Research Programs Grant SC090339, the Adelson Medical Research Foundation, and the National Multiple Sclerosis Society. We are grateful to Tricia Protack and Tracy Ali for technical support, Devin Chandler-Militello for telomerase assays, and Drs. David Pearce and Maiken Nedergaard for equipment support.

Correspondence should be addressed to Dr. Steve Goldman, Department of Neurology, University of Rochester Medical Center, 601 Elmwood Road, Box 645, Rochester, NY 14642.E-mail:Steven_Goldman@urmc.rochester.edu.

F. J. Sim's present address: Department of Pharmacology and Toxicology, University at Buffalo, The State University of New York, Buffalo, NY 14214.

DOI:10.1523/JNEUROSCI.1320-12.2012

Copyright $\odot 2012$ the authors $\quad 0270-6474 / 12 / 3215066-10 \$ 15.00 / 0$
}

intermediate, $\beta$-catenin (Meng et al., 2000); as such, PTPRZ1 may determine the cytosolic and hence nuclear availability of $\beta$-catenin and hence the activation by $\beta$-catenin of T cell factor (TCF)-dependent transcription (Korinek et al., 1997). Accordingly, we have previously noted the significant differential expression of Wnt-TCF target genes by fetal human OPCs (Sim et al., 2011).

The signaling of Wnt ligands through their Frizzled receptors promotes the cytosolic accumulation and nuclear translocation of $\beta$-catenin via the sequestration and inhibition of glycogen synthase kinase $3 \beta$ (GSK3 $\beta$ ), which would otherwise phosphorylate $\beta$-catenin on serine to initiate its proteosomal destruction (Peifer et al., 1994; Korinek et al., 1997; Gordon and Nusse, 2006; van Amerongen and Nusse, 2009). In the nucleus, $\beta$-catenin displaces the transcriptional repressor Groucho/TLE by binding to TCF3 (TCF7L1) and TCF4 (TCF7L2), thereby initiating transcription (Daniels and Weis, 2005; Buscarlet and Stifani, 2007). In the absence of Wnt ligands, $\beta$-catenin availability is diminished by both its GSK3 $\beta$-mediated serine phosphorylation-dependent degradation and its tyrosine phosphorylation-dependent sequestration by membrane-bound cadherins (Nelson and Nusse, 2004; Kam and Quaranta, 2009).

In OPCs, constitutively activated $\beta$-catenin delays both developmental myelination and myelin repair (Fancy et al., 2009) and may act as a negative regulator of terminal oligodendrocytic differentiation (Azim and Butt, 2011). Conversely, histone deacety- 
lases and the thyroid hormone-induced Sox17 are positive regulators of oligodendrocytic differentiation due to their suppression of $\beta$-catenin/TCF binding and transcription (Ye et al., 2009; Chew et al., 2011). These observations suggest that Wnt/ $\beta$ catenin/TCF-dependent gene expression might suppress the terminal differentiation of OPCs. We thus asked whether $\beta$-catenin signaling might be critical to the maintenance and expansion of human OPCs, and whether this process might be regulated not only by canonical Wnt signals but also through an alternative pathway regulated by PTPRZ1 and pleiotrophin.

To this end, we studied human fetal PDGFR $\alpha^{+} \mathrm{CD} 140 \mathrm{a}^{+}$ cells, which comprise the subpopulation of $\mathrm{A} 2 \mathrm{~B} 5{ }^{+}$glial progenitor cells that includes the entire pool of potentially myelinogenic OPCs (Sim et al., 2011). Using PDGFR $\alpha /$ CD140a ${ }^{+}$cells sorted from 16-23 week gestational age fetal brain tissue, we asked whether pleiotrophin could modulate the expansion competence of OPCs and, if so, whether this was effected through PTPRZ1 and $\beta$-catenin-dependent signals. We found that lentiviral short hairpin RNA interference (shRNAi) knockdown of PTPRZ1 substantially augmented the GSK3 $\beta$ inhibition-associated, TCFregulated transcription of a luciferase reporter; this observation suggested the importance of PTPRZ1 as a brake on TCF-dependent gene expression. Pharmacological inhibition of GSK3 $\beta$ triggered substrate detachment and initiated sphere formation, yet had a demonstrable effect on proliferation. In contrast, pleiotrophin significantly potentiated the proliferation of OPCs. Furthermore, PTPRZ1 knockdown sustained the long-term passage of OPCs, significantly delaying their mitotic senescence, as did pleiotrophin. Reflecting the greater availability of $\beta$-catenin afforded by PTPRZ1 suppression, pleiotrophin maintained self-renewing OPCs, suppressing their oligodendrocytic maturation without imparting any bias toward astrocytic differentiation. We thus propose that the inhibition of PTPRZ1 by both autocrine and paracrine sources of pleiotrophin contributes to the sustained self-renewal and homeostatic maintenance of OPCs while suppressing their terminal differentiation.

\section{Materials and Methods}

Isolation of fetal human oligodendrocyte progenitor cells. Samples were obtained under protocols approved by the University of RochesterStrong Memorial Hospital Research Subjects Review Board (Rochester, NY). Fetal brain tissue of either sex was obtained at 16-23 weeks gestational age, always within $2 \mathrm{~h}$ of extraction. Cortical tissue was dissected, and minced samples were dissociated to single cells using papain and DNase as described (Roy et al., 1999). The resultant cells were maintained overnight in serum-free medium (DMEM/F12, 17.9 mM HEPES, $5 \mu \mathrm{g} / \mathrm{ml}$ insulin, 6.35 mM L-glutamine, $46.4 \mathrm{~mm}$ D-glucose, $1.5 \mathrm{~mm}$ sodium pyruvate, $0.2 \mathrm{~mm}$ nonessential amino acids, $40 \mu \mathrm{l} / \mathrm{ml}$ penicillin/streptomycin, $0.0673 \mu \mathrm{g} / \mathrm{ml}$ progesterone, $92.1 \mu \mathrm{g} / \mathrm{ml}$ putrescine, $0.055 \mu \mathrm{g} / \mathrm{ml}$ selenite, $5 \mu \mathrm{g} / \mathrm{ml}$ transferrin) supplemented with $20 \mathrm{ng} / \mathrm{ml}$ FGF2 (Sigma-Aldrich). The day after dissociation, cells were prepared for either magnetic-activated cell separation or fluorescence-activated cell sorting, each based on immunoisolation of platelet-derived growth factor (PDGF) receptor $\alpha$ (PDGFR $\alpha$ ) immunoreactive cells via the CD140a extracellular epitope (2.1 $\mu \mathrm{g}$ anti-CD140a IgG/10 ${ }^{6}$ cells; BD PharMingen) (Sim et al., 2011). After sorting, cells were maintained in serum-free medium as described above, supplemented with $20 \mathrm{ng} / \mathrm{ml}$ PDGF-AA and $20 \mathrm{ng} / \mathrm{ml}$ fibroblast growth factor 2 (FGF2) on untreated suspension plates (Falcon) unless otherwise noted.

Lentiviral PTPRZ1 shRNAi construction. PTPRZ1 expression was suppressed using a lentiviral construct containing a shRNAi sequence against PTPRZ1 followed by CMV:EGFP as described previously (Sim et al., 2006). The sequence used for the PTPRZ1 shRNAi (5'-TGTGAGAA ATATGAACCAGTTTCAAGAGA-3') was scrambled for the control sequence $\left(5^{\prime}\right.$-TGCCGCGTTAGGTTAATCACTTCAAGAGA-3'). In the U373 human glioblastoma cell line, this construct decreases PTPRZ1 expression by over $90 \%$ (Sim et al., 2006). PTPRZ1 shRNAi knockdown
(PTPRZ1kd) was compared to cells infected with a lentiviral construct from the same backbone (pLL3.7) containing the nontargeting, scrambled sequence (Scrambled). The viruses were simultaneously titered on $293 \mathrm{~T}$ cells based upon enhanced green fluorescent protein (GFP) expression (Sim et al., 2011). Fetal OPCs were infected overnight at 1 multiplicity of infection (MOI) 1 week postsort. At $48 \mathrm{~h}$ postinfection, $>80 \%$ of the cells expressed GFP (data not shown).

TCF transcriptional reporter assay. To assess TCF-dependent transcription, we used lentiviral expression of a TCF luciferase reporter (TOPFLASH). In brief, a 539 bp cassette containing the TOPTK sequence from pTOPFLASH (Millipore) was custom synthesized and cloned into pUK21 along with flanking AttL4 and R1 recombination sites (BlueHeron). TOPFLASH was constructed using Gateway recombination and pLenti6/R4R2/V5-DEST (Invitrogen) and pENTRluciferase plasmids. An HT1080 plaque forming colony assay was used to determine the titer. OPCs were infected at 1 MOI. The TOPFLASH lentiviral construct was validated using $\mathrm{LiCl}$ and $\mathrm{NaCl}$ as a positive and negative control, respectively, in HEK293T cells. The ability of $2^{\prime} Z, 3^{\prime} E$ )-6-bromoindirubin-3'-oxime (BIO) to activate TCF activity using the TOPFLASH construct was then validated in HEK293T cells and rat A2B5 ${ }^{+}$OPCs. Following a 7 day recovery postsort, CD140a/PDGFR $\alpha^{+}$-sorted OPCs were infected with the lentiviral TOPFLASH construct for BIO/MeBIO studies or, for the other experiments, with PTPRZ1k or Scrambled. Seven days after infection with lentiviral PTPRZ1kd or Scrambled virus, the cells were infected again with lentiviral TOPFLASH. Due to limited cell number, 17 and $19.6 \mathrm{wk}$ samples were expanded before passaging and replated for TOPFLASH infection. One day after infection with lentiviral TOPFLASH, OPCs were then treated for $24 \mathrm{~h}$ with BIO or MeBIO (Calbiochem). The cells were then lysed and exposed to a luciferase substrate (BrightGlo, Promega), and luminescence was read by spectrophotometry in triplicate. Samples with relative light units (RLU) $<100$ were removed from analysis. Statistical analysis was performed using Prism (GraphPad).

$\beta$-catenin cellular localization. OPCs were plated on Permanox-treated slides (Nunc) in $20 \mathrm{ng} / \mathrm{ml}$ PDGF-AA and $20 \mathrm{ng} / \mathrm{ml} \mathrm{FGF2} \mathrm{for} 7 \mathrm{~d}$. Cells were then removed from growth factors and treated with either the GSK- $3 \beta$ antagonist BIO (GSK-3 inhibitor IX, 62 nM; Calbiochem), its inactive control, methylated BIO (MeBIO, GSK-3 inhibitor IX control, $62 \mathrm{~nm}$; Calbiochem), or the $18 \mathrm{kDa}$ glycosylated form of pleiotrophin (50 $\mathrm{ng} / \mathrm{ml}$; P 5333, Sigma). At the conclusion of the treatment, cells were fixed in $4 \%$ paraformaldehyde (PFA) and stained for NG2 (OPC membrane marker, 1:200; catalog no. MAB2029, Millipore). Secondary immunochemistry of NG2 was performed using biotinylated anti-mouse IgG (1:200, $2 \mathrm{~h}$ at room temperature). Tertiary staining used streptavidin 568 (1:500, $1 \mathrm{~h}$ at room temperature). Subsequent to NG2 staining, cells were washed and stained for $\beta$-catenin (clone 14, 1:500; BD Bioscience), Olig2 (1:1000; Neuromics), and DAPI (1:1000). Slides were then stained with immunofluorescent secondary antibodies (1:400, 1 h; Alexa Fluor 488 goat anti-mouse IgG1 and Alexa Fluor 547 goat anti-rabbit IgG, respectively). The staining protocol was verified using isotype controls in single, double, and triple combinations. The chamber wells were removed and the slides were coverslipped with Vectashield and analyzed using four-color confocal microscopy.

Cell proliferation. CD140a/PDGFR $\alpha$-sorted OPCs were allowed to recover from sorting for $7 \mathrm{~d}$. OPCs were then expanded in the presence of PDGF-AA and FGF2 and either $62 \mathrm{~nm}$ BIO, 62 nм MeBIO, or pleiotrophin $(25 \mathrm{ng} / \mathrm{ml})$ for 2 weeks in all conditions. At that point, the OPCs were either left in PDGF-AA- and FGF2-containing medium or switched to medium free of exogenous mitogens for $7 \mathrm{~d}$ so as to initiate differentiation. As a negative control, we treated one population of PDGF/FGF2maintained cells with $1 \mathrm{~mm}$ cytosine arabinoside (AraC) for $24 \mathrm{~h}$ so as to arrest the cell cycle. At this time, the total number of spheres in each 6-well plate was counted using bright field microscopy. Cells were pulsed for $4 \mathrm{~h}$ with $1 \mu \mathrm{M}$ 5-ethyldeoxyuridine (EdU), and then immediately passaged using papain, fixed, and counted. We only pulsed for $4 \mathrm{~h}$ to eliminate cells going through mitosis more than once. Cells were stained with Click-iT technology according to the manufacturer's directions (catalog no. A10202, Invitrogen). Propidium iodide (PI) was used to 
assess total DNA content. Flow cytometry was performed on the BD FACSAria (BD Biosciences) and analyzed using FlowJo software with at least 100,000 events per condition before analysis (TreeStar). After forward scatter and side scatter gating to remove debris and clusters, PI gating was used to isolate whole nuclei and exclude DNA fragments. High EdU incorporation and high PI-defined DNA content typify cells in S-phase. Cells in $G_{1}$ have low PI and no EdU staining, while $G_{2} M$ is marked by high PI content, but little acute EdU incorporation. Statistical analysis was performed on Prism (GraphPad), and data were reported as mean $\pm \mathrm{SD}$.

To permit the long-term propagation of PTPRZ1 knockdown, scrambled and uninfected OPCs were maintained in PDGF-AA and FGF2 on plastic and passaged regularly at $75 \%$ confluence. Cell counts were taken at every passage. Relative expansion was calculated by sequentially multiplying the fold changes in cell number occurring with each passage. Population doublings were calculated as the $\log _{2}$ of relative expansion at 9 months in vitro.

Phenotypic determination. CD140a-sorted fetal human OPCs were plated onto poly-L-ornithine and fibronectin-coated plates at 50,000 cells $/ \mathrm{ml}$ in serum-free medium containing PDGF-AA (20 ng/ml), FGF2 (20 ng/ml), and NT3 $(2 \mathrm{ng} / \mathrm{ml})$. Following a $7 \mathrm{~d}$ recovery, cells were treated with either pleiotrophin (25 ng/ml), potassium bisperoxo(1,10-phenanthroline)oxovanadate $(\mathrm{V})$-referred to as oxovanadate or bpV(phen) (2.5 nM) - or vehicle control for $7 \mathrm{~d}$. Cells were lightly fixed (1\% PFA), and adjacent wells were immunolabeled with either the oligodendrocyte progenitor marker A2B5 (1:500, $1 \mathrm{~h}$ at room temperature; Millipore Bioscience Research Reagents) or the oligodendrocyte marker O4 (1:1000 overnight; Millipore Bioscience Research Reagents), followed by Alexa 488-conjugated goat antimouse IgM ( $1 \mathrm{~h}$ at room temperature). Cells were then washed and fixed (4\% PFA, $5 \mathrm{M}$ ) before staining for glial fibrillary acid protein (GFAP, SMI21, 1:000, overnight; Covance) or $\beta$ III-tubulin/TUJ1 (1:1000, overnight), followed by isotype-specific secondary antibodies (Alexa Fluor 594-conjugated goat anti-mouse $\operatorname{IgG}_{1}$ or goat anti-mouse $\operatorname{IgG}_{2 \mathrm{a}}$, each $1: 400,1 \mathrm{~h}$ at room temperature). Cell counts were taken from 10 randomly chosen fields distributed across each well, comprising at least 250 total cells. All statistical analyses were performed using Prism (GraphPad).

Nuclear extraction and immunoblotting. Passaged cells stably transduced with either scrambled or PTPRZ1 shRNAi were sorted and infected as described above in the previous paragraphs and then plated at $2.5 \times 10^{5}$ cells $/ \mathrm{ml}$. After $7 \mathrm{~d}$, the cells were treated for $2 \mathrm{~h}$ with either 125 $\mathrm{nm}$ BIO, $125 \mathrm{~nm}$ MeBIO, $100 \mathrm{ng} / \mathrm{ml}$ pleiotrophin, or $125 \mathrm{~nm}$ BIO and 100 $\mathrm{ng} / \mathrm{ml}$ pleiotrophin. The cells were removed from the dish using papain and rinsed in PBS. Cytoplasmic and nuclear extraction was performed according to manufacturer's directions (Pierce, NE-PER kit). Protein was quantified using a BCA assay (Pierce). Invitrogen Nu-PAGE 4-12\% Bis-Tris gels, a PVDF membrane, and GE Healthcare ECL detection reagent and film were used for Western immunoblotting. The Western was blotted using antibody directed against $\alpha$-activated $\beta$-catenin, nonphosphorylated at Ser37/Thr41 (clone 8E7, $2 \mu \mathrm{g} / \mathrm{ml}$; Millipore). The Western blot was then stripped using ReBlot Strong solution (Millipore), and reblotted using a pan-specific (all forms) anti- $\beta$-catenin antibody (clone H-102, 1:100; Santa Cruz Biotechnology) and subsequently with anti-GAPDH (glyceraldehyde 3-phosphate dehydrogenase) as a normalization control (clone 6C5, 1:5000; Abcam).

\section{Results}

In this study, we asked whether $\beta$-catenin signaling and its regulation by GSK $3 \beta$ might be critical to both the maintenance and expansion of human OPCs and, furthermore, whether this process might be regulated not only by Wnt-Frizzled signaling, but through an alternative pathway regulated by PTPRZ1 (protein receptor tyrosine phosphatase $\beta / \zeta$ ) and its inhibitory ligand pleiotrophin. Since our goal was to identify and evaluate potential therapeutic targets, we focused our study on human OPCs, given the significant differences in both gene expression and phenotype between murine and human OPCs (Sim et al., 2009). To this end, we used CD140a/PDGFR $\alpha$ to isolate OPCs from human neocortical tissue derived from 16-22 week gestational age fetuses as described previously (Sim et al., 2011). CD140a ${ }^{+}$cells could be maintained in vitro as bipotential proliferative OPCs and continued to express PDGFR $\alpha$ for at least 1 week postsort (Fig. 1A).

\section{GSK3 $\beta$ inhibition increased TCF-dependent transcription}

We first asked whether fetal human OPCs could activate Wnt/ $\beta$-catenin pathway signaling; to this end, we assessed whether GSK3 $\beta$ inhibition increased TCF-dependent transcription by using a TCF-dependent luciferase reporter. Specifically, CD140a-sorted cells were infected with the lentiviral TOPFLASH construct, which is comprised of a multimeric TCFdriven luciferase. Over $80 \%$ of cells infected with a control lentiviral CMV:GFP expressed GFP within $48 \mathrm{~h}$, obviating the need for further selection. The cells were then exposed to the GSK3 $\beta$ inhibitor BIO, an indirubin with high specificity for GSK3 $\beta$ (Meijer et al., 2003), and compared it to its inactive methylated control (MeBIO). Luminometry revealed that TCF-driven luciferase activity was 1.84 -fold higher in OPCs treated with 62 nM BIO versus MeBIO (213 $\pm 138.5 \mathrm{RLU}$ vs $116 \pm 60.3 \mathrm{RLU} ; p<$ 0.05 by two-way ANOVA; $n=13$, Fig. $1 B$ ). Exposure to $31 \mathrm{~nm}$ $\mathrm{BIO}$ yielded a 1.6-fold elevation in TCF activity compared to MeBIO-treated cells $(120 \pm 49.6$ vs $75 \pm 18.3$ RLU; one-way ANOVA, $p=0.0402, n=6$ ) (Fig. $1 B$ ). Doses of $\geq 125 \mathrm{~nm} \mathrm{BIO}$ proved toxic (data not shown). GSK3 $\beta$ inhibition was thus associated with a dose-dependent increase in TCF activity, indicating that human OPCs can dynamically regulate TCF transcription.

\section{GSK3 $\beta$ inhibition in OPCs results in the translocation of $\boldsymbol{\beta}$-catenin}

The modulation of TCF-dependent transcription by GSK3 $\beta$ inhibition indicated that OPCs retain the capacity to actively signal via $\beta$-catenin-driven TCF promoter activation; this in turn suggested that GSK $3 \beta$ inhibition would be attended by $\beta$-catenin translocation. To monitor $\beta$-catenin localization, we plated fetal human CD140a ${ }^{+}$OPCs on Permanox-coated slides (Nunc) so as to directly visualize the intracellular transit of $\beta$-catenin via confocal microscopy. We did this in the absence of growth factors so as to minimize any incidental $\beta$-catenin activation by constituents of the ambient culture medium. In control cells treated with inactive MeBIO (62 nM) for $1 \mathrm{~h}$, we noted little immunodetectable cytosolic $\beta$-catenin, the localization of which was largely restricted to terminal processes at points of membrane juxtaposition (Fig. $1 D$ ). In contrast, GSK $3 \beta$ inhibition by the active moiety $\mathrm{BIO}(62 \mathrm{~nm})$ yielded a rapid fall in membrane-localized $\beta$-catenin in OPCs, which were concurrently validated by coexpression of Olig2 and NG2 (Fig. $1 E$, arrows). These observations suggest the departure of $\beta$-catenin from its membrane-bound docking sites, a critical rate-limiting step in its nuclear translocation. Furthermore, within $6 \mathrm{~h}$ of exposure to $62 \mathrm{~nm} \mathrm{BIO,}$ OPCs exhibited increased membrane-associated as well as cytosolic $\beta$-catenin immunolabeling (Fig. $1 F$ ) compared to MeBIO-treated controls (Fig. $1 D$ ). In addition, both cytoplasmic and nuclear accumulation of $\beta$-catenin, as triggered by the GSK $3 \beta$ inhibitor BIO, was confirmed by Western blotting (see Fig. $3 E$ ). This suggests that the BIO-mediated inhibition of GSK $3 \beta$-dependent $\beta$-catenin degradation results in the membrane and cytosolic accumulation of signal-competent $\beta$-catenin, thus enabling TCF-mediated signaling. 

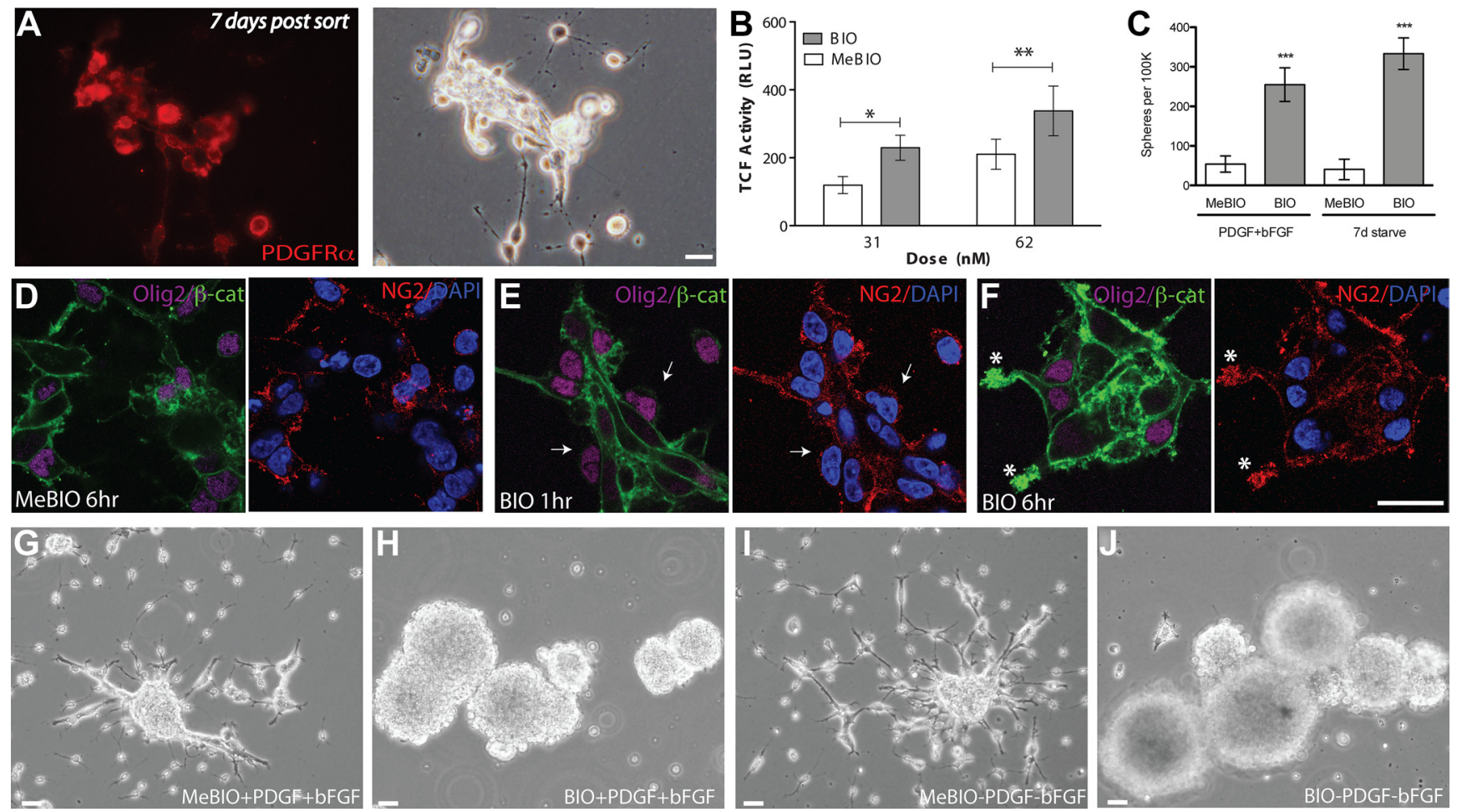

Figure 1. GSK3 $\beta$ inhibition potentiated $\beta$-catenin translocation and TCF transcription in human fetal OPCs. $\boldsymbol{A}$, CD140a/PDGFR $\alpha$-sorted fetal human oligodendrocyte progenitor cells, OPCs, retain characteristic bipolar morphology and PDGFR $\alpha$ expression for at least 7 days in vitro (DIV). $\boldsymbol{B}$, At 7 DIV, the ability of OPCs to initiate Wnt pathway gene transcription was tested using a GSK3 $\beta$ inhibitor, bromo-indirubin-oxime or BI0, and a luciferase reporter, TOPFLASH. Indeed, BIO increased luciferase expression in a dose-dependent manner. C, Fetal human OPCs formed spheres in response to BI0-mediated GSK3 $\beta$ inhibition. BIO significantly increased the number of spheres per $10^{5}$ plated cells relative to MeBI0 control-treated cultures when assessed after $7 \mathrm{~d}$ of drug exposure. This effect was independent of mitogen addition, which did not increase the number or proportion of spheres generated. $\boldsymbol{D}-\boldsymbol{F}$, To verify that $G S K 3 \beta$ inhibition was effecting TCF activation through altering localization of $\beta$-catenin, the Wnt signaling intermediate, $\beta$-catenin, was localized by confocal imaging in OPCS, validated as such by their coexpression of 0 lig 2 and $N G 2$. D, In the absence of growth factors, immunodetectable $\beta$-catenin was largely restricted to process tips and points of intercellular contact (MeBI0 inactive control, 62 nM). , GSK3 $\beta$ inhibition by BI0 initially diminished membrane localizable $\beta$-catenin (arrows). $\boldsymbol{F}$, After $6 \mathrm{~h}$ of treatment, BI0-treated OPCs exhibited increased $\beta$-catenin expression (asterisks), reflecting decreased degradation. $\mathbf{G}-\boldsymbol{J}$, BI0-mediated GSK3 $\beta$ inhibition initiated sphere formation in both proliferative (PDGF-AA and FGF2 supplementation) and differentiating (no growth factors) conditions. Scale bars, $20 \mu \mathrm{m}$. ${ }^{*} p<$ $0.01,{ }^{* *} p<0.001$.

\section{GSK3 $\beta$ inhibition potentiated in vitro expansion as spheres without influencing proliferation}

We next asked whether BIO-mediated inhibition of GSK3 $\beta$ influenced the expansion of OPCs. We found that when raised in suspension culture in the presence of the mitogens PDGF and FGF2, BIO treatment induced the robust formation of minimally adherent spheres $\left(255 \pm 42.6\right.$ spheres $/ 10^{5}$ cells plated vs $54 \pm$ 20.5 in MeBIO-treated controls; $n=9 /$ condition) (Fig. $1 C, G, H$ ). Most cells within each sphere expressed either the oligodendroglial lineage transcription factor Olig2, which is expressed by glial progenitor cells, or the astrocytic glial fibrillary acid protein GFAP (data not shown). Surprisingly, the strong potentiation of sphere formation by BIO persisted independently of mitogen exposure; in OPC cultures prepared in the absence of added PDGF or FGF2, $333 \pm 40.0$ spheres $/ 10^{5}$ cells were generated in BIO-treated cultures versus $40 \pm 25.9$ spheres $/ 10^{5}$ cells in their MeBIO-exposed controls ( $n=7 /$ condition) (Figs. $1 C, I, J$ ). Thus, whereas the effect of $\mathrm{BIO}$ on sphere formation was highly significant $\left(F_{(1,24)}=50.48\right.$ by two-way ANOVA; $\left.p<0.0001\right)$, mitogen exposure had no significant effect on sphere incidence $\left(F_{(1,24)}=\right.$ $1.15, p=0.29)$. However, hemocytometer counts revealed that despite the BIO-associated increase in the number of spheres, the total number of cells was not influenced by BIO whether in the presence $\left(9.8 \times 10^{5} \pm 5.9 \times 10^{5} \mathrm{BIO}\right.$ vs $9.7 \times 10^{5} \pm 6.0 \times 10^{5}$ $\mathrm{MeBIO})$ (Fig. $2 \mathrm{~A})$ or absence $\left(5.3 \times 10^{5} \pm 3.5 \times 10^{5} \mathrm{BIO}\right.$ vs $\left.5.0 \times 10^{5} \pm 3.1 \times 10^{5} \mathrm{MeBIO}\right)$ of the growth factors FGF2 and
$\operatorname{PDGF}\left(p=0.91\right.$ by two-way ANOVA, $\left.F_{(1,29)}=0.01\right)$. Similarly, BIO-treated spheres did not propagate any longer or more efficiently than did their MeBIO-treated controls in serial passage (data not shown). In contrast, mitogen addition resulted in increased cell number with upon passage (MeBIO/PDGF/FGF2, $F_{(1,29)}=6.86$ by two-way ANOVA, $\left.p=0.01\right)$. Importantly, we found no evidence for any interaction between BIO-mediated GSK3 $\beta$ inhibition and mitogen exposure, suggesting the mechanistic independence of these influences $\left(F_{(1,29)}=0.00\right.$, by twoway ANOVA, $p=0.95$ ).

Since sustained exposure to $\mathrm{BIO}$ promoted expansion as gliospheres in suspension culture and yet had no effect on the number of total OPCs, we asked whether BIO-initiated sphere expansion was a product of mitotic activity or of altered adhesive interactions. To this end, we asked whether GSK3 $\beta$ inhibition increased either the proliferation rate or mitotic fraction of OPCs and used the incorporation of a thymidine analog, EDU (5ethyldeoxyuridine), to assess proliferation. Following sustained treatment for 1 month with $\mathrm{BIO}$ or MeBIO, we exposed OPCs for $4 \mathrm{~h}$ to $1 \mu \mathrm{M}$ EdU, passaged, and then fixed the cells for immunolabeling and flow cytometry. Forward scatter and side scatter gating were used to discriminate debris and clusters, and PI (propidium iodide) was used to mark DNA, thereby identifying whole nuclei and excluding fragments. In addition, AraC (cytosine arabinoside) mitotic blockade was used to calibrate the gates by which S-phase-associated EdU incorporation was defined. Using 
this protocol, $10.9 \pm 1.4 \%$ of MeBIOtreated control cells incorporated EdU when cultured in PDGF and FGF2 $(n=5$ experiments; Fig. 2B). Removal of FGF2 and PDGF for $7 \mathrm{~d}$ diminished the incidence of EdU-incorporation by these cells $\left(8.1 \pm 2.1 \%, n=5 ; F_{(1,16)}=6.63\right.$ by twoway ANOVA, $p=0.02$ ), consistent with the hemocytometer cell counts and the known mitogenic effects of these agents (Figs. 2A, B,D). However, BIO-mediated GSK3 $\beta$ inhibition did not increase the incidence of proliferating OPCs in either the presence $(11.2 \pm 5.1$ vs $10.9 \pm 1.4 \%)$ or absence $(6.4 \pm 1.8$ vs $8.1 \pm 2.1 \%)$ of growth factors $\left(n=5\right.$ each; $F_{(1,16)}=0.26$, $p>0.05$ ) (Figs. $2 B-D$ ). Similarly, neither the percentage of cells in $\mathrm{G}_{0} / \mathrm{G}_{1}$ and $\mathrm{G}_{2} \mathrm{M}$ nor the total cell number differed significantly between BIO and MeBIO-treated groups (data not shown). These data further suggest that while GSK3 $\beta$ inhibition altered the anchorage-dependent pattern of growth of OPCs to promote sphere formation, it was insufficient to significantly influence the mitotic index or cell cycle activity of these cells.

\section{PTPRZ1 inhibition increased}

\section{TCF-dependent transcription}

Although $\beta$-catenin signaling may be initiated by Wnt ligands acting through Frizzled receptors and associated coreceptors, it may also be both triggered and modulated by other means. In particular, the receptor protein tyrosine phosphatase $\beta / \zeta$, the product of the PTPRZ1 gene, constitutively dephosphorylates $\beta$-catenin and may act as a tonic brake upon $\beta$-catenin signaling (Meng et al., 2000). Yet, as noted, PTPRZ1 is negatively regulated by the soluble ligand pleiotrophin, which may thereby potentiate $\beta$-catenin signaling and TCF-dependent transcription. This was especially interesting since the gene expression profile of fetal human tissue-derived OPCs manifests high levels and differential expression of both pleiotrophin and PTPRZ1 genes, as well as TCF-dependent genes involved in cell cycle, suggesting the potential for autocrine control of TCF-dependent transcription by OPCs in the human brain (Sim et al., 2011).

On that basis, we next asked whether inhibition of PTPRZ1 by shRNAi knockdown might influence TCF-dependent luciferase transcription, both alone and together with GSK3 $\beta$ inhibition. We found that TCF-mediated transcription increased by 1.93 -fold in OPCs with lentiviral knock-down of PTPRZ1 (PTPRZ1kd) relative to control OPCs infected with lentivirus encoding scrambled shRNAi $(239 \pm 92.6 \mathrm{RLU}$ in PTPRZ1kd OPCs vs $124 \pm 34.9 \mathrm{RLU}$ in Scrambled infected cells, $n=4 ; F_{(1,12)}=32.82$ by two-way ANOVA, $p<0.0001$, with Bonferroni post hoc $t$ test;) (Fig. 3A). Addition of 62 nM BIO to PTPRZ1kd OPCs further increased TCF-luciferase activity significantly $(466 \pm 70.6 \mathrm{RLU}$ for BIO-treated PTPRZ1kd OPCs vs $384 \pm 87.0 \mathrm{RLU}$ for MeBIO-treated Scrambled infected OPCs, $n=4$ experiments; $F_{(1,12)}=22.17$ by two-way ANOVA, $p=$ 0.0005 by Bonferroni post hoc $t$ test). These data indicate that PTPRZ1 knockdown via lentiviral shRNAi tonically increased TCFdependent transcription, and that GSK3 $\beta$ inhibition significantly potentiated this process. Together, these observations suggest that two pools of $\beta$-catenin, which are regulated by PTPRZ1 and GSK3 $\beta$, are partially but incompletely overlapping, with GSK $3 \beta$ appearing to regulate $\beta$-catenin availability beyond that influenced by receptor protein tyrosine phosphatase $\beta / \zeta$ activity. Combined PTPRZ1 and GSK3 $\beta$ inhibition might be anticipated by OPCs responding to concurrent Wnt and pleiotrophin signals. Indeed, we noted a significant interaction between GSK3 $\beta$ inhibition and PTPRZ1 knockdown $\left(F_{(1,12)}=4.94\right.$ by two-way ANOVA; $p=0.046$ by Bonferroni post hoc $t$ test), suggesting synergistic potentiation of TCF-dependent gene expression (Fig. 3A).

\section{PTPRZ1 inhibition potentiated GSK3 $\beta$-regulated $\beta$-catenin translocation}

Confocal imaging of cultured OPCs revealed that pleiotrophin $(50 \mathrm{ng} / \mathrm{ml})$ robustly increased the cytosolic accumulation of $\beta$-catenin and did so rapidly, with demonstrable increments within $1 \mathrm{~h}$ of exposure (Fig. 3C). As might be expected from their tandem effects on TCF-dependent transcription, pleiotrophin and BIO-mediated GSK3 $\beta$ inhibition (62 nM) yielded a greater cytosolic accumulation of $\beta$-catenin than that achieved by either treatment alone (Fig. 3D). We confirmed the accumulation and translocation of $\beta$-catenin, using Western blotting of cytoplasmic and nuclear extracts of CD140a-sorted cells infected with lentiviral shRNAi against PTPRZ1 (PTPRZ1kd) (Fig. 3E).

Activated $\beta$-catenin (ABC) is designated as such due to the lack of phosphorylation at the residues (Ser37/Thr41) targeted by GSK3 $\beta$. Neither cytoplasmic nor nuclear extracts had detectable amounts of ABC in control cells (Scrambled, MeBIO). In contrast, PTPRZ1kd cells exhibited ABC in the cytoplasm and in the nucleus that was increased further by treatment with the GSK3 $\beta$ inhibitor BIO. Indeed, BIO treatment increased the levels of both $\mathrm{ABC}$ and total $\beta$-catenin compared to MeBIO in both Scrambled and PTPRZ1kd cells. As expected, pleiotrophin treatment similarly increased both cellular $\beta$-catenin and its nuclear translocation in the control (scrambled RNAi)-infected cells. Yet, in 

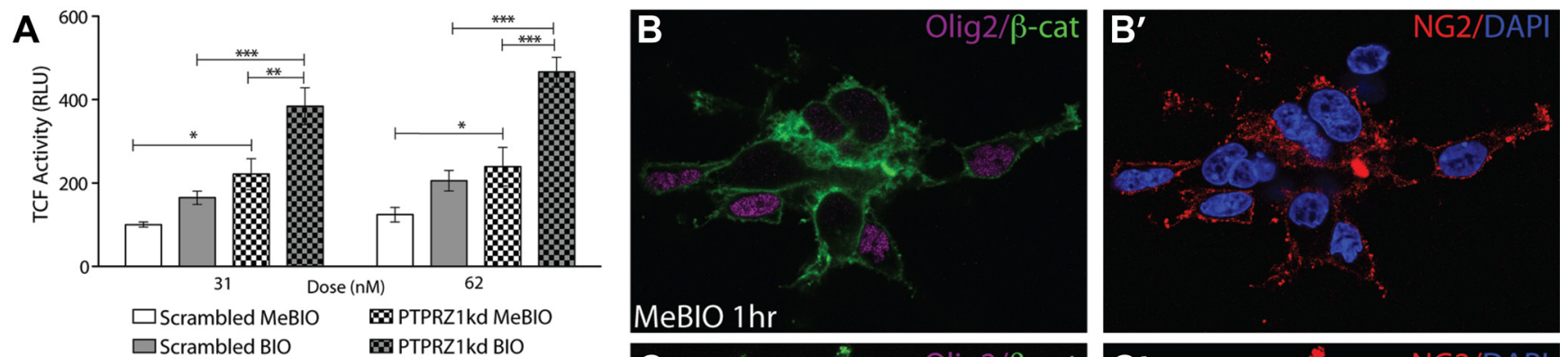

$\mathbf{E}$
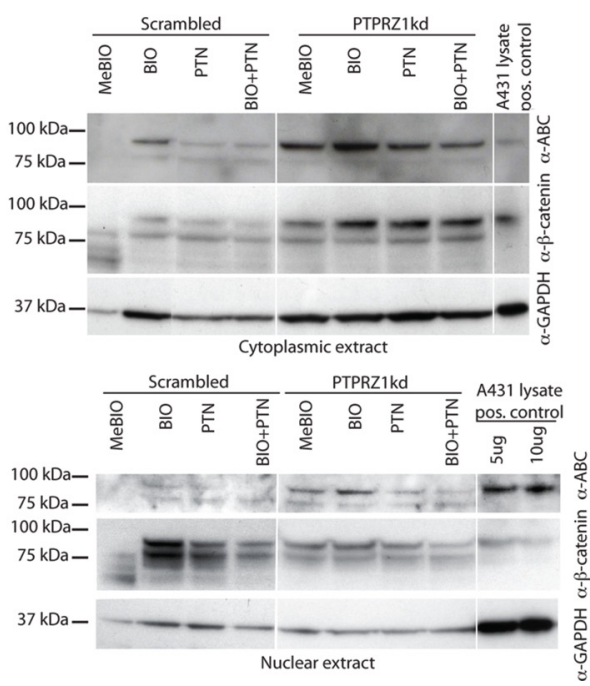
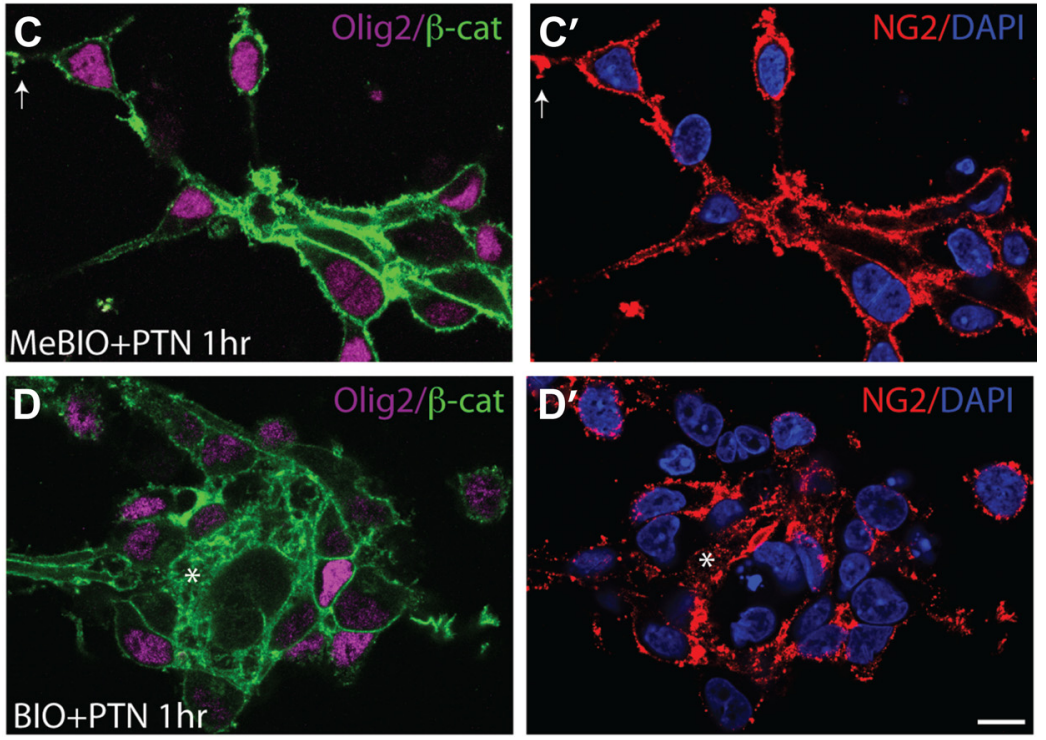

Figure 3. Inhibition of both PTPRZ1 and GSK3 $\beta$ increase cytosolic and nuclear $\beta$-catenin. $A$, To test PTPRZ1 in the regulation of the $\beta$-catenin/TCF pathway, we used PTPRZ1 knockdown, PTPRZ1kd, in conjunction with a TCF reporter, TOPFLASH. Knockdown of PTPRZ1 increased TCF activity relative to controls infected with lentiviral scrambled shRNAi; the increment in TCF-dependent luciferase activity associated with PTPRZ1 knockdown exceeded that afforded by GSK3 $\beta$ inhibition in scrambled-infected controls. Furthermore, PTPRZ1kd increased TCF activity synergistically with GSK3 $\beta$ inhibition by BIO. One-way ANOVA with posthocttests; ${ }^{*} p<0.05,{ }^{* *} p<0.01,{ }^{* * *} p<0.001$. $\boldsymbol{B}$ - $\boldsymbol{D}$, To verify that PTPRZ1kd was activating TCF-dependent transcription by altering $\beta$-catenin trafficking, we localized $\beta$-catenin by confocal imaging of PDGFR $\alpha$-sorted fetal human OPCs, using either 0lig2 (purple, $\boldsymbol{B}-\boldsymbol{D}$ ) or NG2 (red, $\boldsymbol{B}^{\prime}-\boldsymbol{D}^{\prime}$ ). $\boldsymbol{C}$, In the absence of other added growth factors, pleiotrophin (PTN) exposure was sufficient to

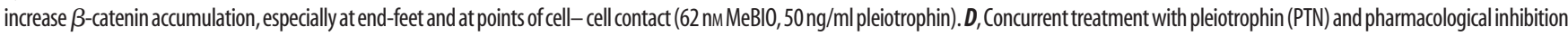
of GSK3 $\beta$ using BIO (62 nM) increased $\beta$-catenin immunolabeling and cytoplasmic availability (example denoted by asterisk). $\boldsymbol{E}$, Western blotting was used to verify cytoplasmic accumulation and nuclear translocation of $\beta$-catenin in extracts of both PTPRZ1 shRNAi (PTPRZ1kd)-infected and scrambled shRNAi control-infected CD140a-sorted cells. Both GSK3 $\beta$ inhibition by BI0 and PTPRZ1 inhibition by pleiotrophin promoted the accumulation of $\beta$-catenin in the cytoplasm and nucleus of the control cells transduced with scrambled shRNAi. Furthermore, PTPRZ1kd proved sufficient to enhance $\beta$-catenin availability in all treatment groups, and its effects in this regard were additive with those of BI0-induced GSK3 $\beta$ inhibition. Scale bar, $10 \mu \mathrm{m}$.

PTPRZ1kd cells pleiotrophin did not further change the levels or distribution of $\beta$-catenin, suggesting that pleiotrophin acts via PTPRZ1. These observations indicated that pleiotrophin, via inhibition of PTPRZ1, can increase the pool of activated $\beta$-catenin and may do so over and above that achieved by GSK3 $\beta$ inhibition. PTPRZ1 inhibition and GSK $3 \beta$ inhibition may thus work in conjunction to release membrane bound $\beta$-catenin, and to thereby achieve the cytoplasmic quantities needed for efficient nuclear translocation and TCF transcription.

\section{Pleiotrophin was sufficient to maintain the proliferative expansion of OPCs}

We next asked whether pleiotrophin might directly modulate the mitotic competence of OPCs. To that end, we assessed the proliferation of pleiotrophin-treated OPCs using EdU incorporation and flow cytometry. In the absence of other added growth factors, $25 \mathrm{ng} / \mathrm{ml}$ pleiotrophin increased the proportion of actively cycling cells as defined by incorporation of EdU over $4 \mathrm{~h}(11.5 \pm$ $2.2 \%, n=7$ vs vehicle $7.5 \pm 2.6, n=3$; $[F=3.38]$ by one-way ANOVA, $p=0.041$ ) (Figs. $4 A, B)$. However, in the presence of PDGF and FGF2, pleiotrophin addition did not further raise the mitotic fraction of OPCs $(12.6 \pm 2.4 \%$ in pleiotrophin/PDGF/
FGF2, $n=8$ vs $11.3 \pm 2.5 \%$ in PDGF/FGF2 alone, $n=4)$. The nonadditive nature of pleiotrophin and PDGF/FGF2 signaling may be due to the induction of pleiotrophin expression by PDGF signaling (Antoine et al., 2005), or it might be attributed to the role of PDGFR $\alpha$ mitigating Akt inhibition of GSK3 $\beta$, hence allowing PDGFR $\alpha$ activity to signal via $\beta$-catenin as well as through the MAP kinase pathway (Rosenkranz et al., 1999; Chew et al., 2011). Interestingly, while these experiments were done using suspension cultures, neither pleiotrophin nor PTPRZ1kd induced sphere formation, in contrast to the robust generation of spheres in response to GSK3 $\beta$ inhibition; these data suggest that GSK3 $\beta$ inhibition influences additional pathways besides those involved in self-renewal and mitotic competence.

\section{Oligodendrocyte progenitor self-renewal was sustained by PTPRZ1 knockdown}

Since both pleiotrophin and lentiviral shRNAi knockdown of PTPRZ1 increased the mitotic fraction of CD140a-sorted OPCs, we next asked whether stable knockdown of PTPRZ1 might sustain the self-renewal competence, and hence expansion potential, of the oligodendrocyte progenitor pool. To that end, OPCs infected with either lentiviral shRNAi against PTPRZ1 or 
scrambled shRNAi control virus were propagated for $300 \mathrm{~d}$ with serial in vitro passage when subconfluent. We found that the population of PTPRZ1kd cells, which remained bipolar, $\mathrm{GFP}^{+}$, and $\operatorname{PDGFR} \alpha^{+}$, continued to divide longer and exhibited significantly more population doublings than did their PDGFR $\alpha^{+}$ counterparts infected with scrambled shRNAi, maintaining active proliferation for over 9 months in vitro $(14.1 \pm 3.9$ PDs vs $8.0 \pm 6.0$, respectively, $n=7$ each; $p=$ 0.04 by unpaired $t$ test) (Figs. $4 C$ ). Scrambled infected cells typically did not survive, except if the progenitor cells spontaneously differentiated terminally into astrocytes, which may retain proliferation competence (Fig. 4D). These data suggested that PTPRZ1kd was sufficient to maintain the proliferation of CD140asorted OPCs over time. The prolonged expansion of PTPRZ1kd cells was not due to changes in telomerase activity as measured by a telomeric repeat amplification protocol assay (data not shown); eventually, all cells achieved mitotic senescence and ceased to divide. Thus, PTPRZ1 inhibition significantly prolonged the self-renewal capacity of human fetal OPCs, yet it did not permit the cells to escape senescence.

\section{Pleiotrophin maintains the fetal human oligodendrocyte progenitor phenotype}

We next asked whether pleiotrophin influences the lineage choice of proliferating CD140a ${ }^{+}$human OPCs. We found that the proportion of $\mathrm{A} 2 \mathrm{~B}^{+}{ }^{+} / \mathrm{GFAP}^{-}$OPCs was significantly higher in cultures supplemented for $7 \mathrm{~d}$ with $25 \mathrm{ng} / \mathrm{ml}$ pleiotrophin than in their unsupplemented controls $(31.7 \pm 5.2 \%$ in pleiotrophin vs $18.9 \pm 8.6 \%$ in vehicle, $n=4 ; p=0.044$ by unpaired $t$ test) (Fig. $4 D$ ). Pleiotrophin exposure was concurrently associated with diminished oligodendrocytic production $\left(3.7 \pm 1.1 \% \mathrm{O}^{+}\right.$cells in $25 \mathrm{ng} / \mathrm{ml}$ pleiotrophin vs $14.0 \pm 7.2 \%$ in vehicle, $n=4 ; p=0.029$, unpaired $t$ test) (Fig. $4 E$ ). Pleiotrophin did not affect the small fraction of $\mathrm{GFAP}^{+} / \mathrm{A} 2 \mathrm{~B} 5^{-}$astrocytes $(6.5 \pm 6.8 \%$ in pleiotrophin vs $5.3 \pm 3.6 \%$ in vehicle, $n=3 ; p=0.80$, unpaired $t$ test). These data indicate that pleiotrophin acts to maintain the selfrenewing phenotype of oligodendrocyte progenitor cells at the expense of mature oligodendrocytic differentiation.

Since pleiotrophin acts, at least in part, through the inhibition of PTPRZ1 activity, we next assessed the effects of an oxovanadate tyrosine phosphatase inhibitor on the expansion of fetal human OPCs. We found that at a level of $2.5 \mathrm{nM}$, the oxovanadate $\mathrm{bpV}$ (phen), a potent pan-phosphatase inhibitor that selectively targets receptor tyrosine phosphatases at low concentrations (Posner et al., 1994; Doillon et al., 1999), significantly elevated the proportion of $\mathrm{A} 2 \mathrm{~B} 5{ }^{+} / \mathrm{GFAP}^{-}$OPCs relative to vehicle-exposed controls, from $10.3 \pm 4.2 \%(n=4)$ to $30.9 \pm 6.5 \%(n=3)(p<$ 0.05 by two-way ANOVA). This effect was lost at levels of bpV(phen) $>25 \mathrm{~nm}$, at which point bpV(phen)-related toxicity became manifest in diminished expansion (data not shown). Of note, $\mathrm{bpV}$ (phen) (at $2.5 \mathrm{nM}$ ) did not influence the proportion of either $\mathrm{O}^{+}{ }^{+}$oligodendroglia (12.9 \pm 3.6 vs $14.0 \pm 7.2 \%$ in vehicle, $n=4$ each $)$ or $\mathrm{GFAP}^{+} / \mathrm{A} 2 \mathrm{~B} 5^{-}$astrocytes $(6.5 \pm 6.8$ vs $5.3 \pm$

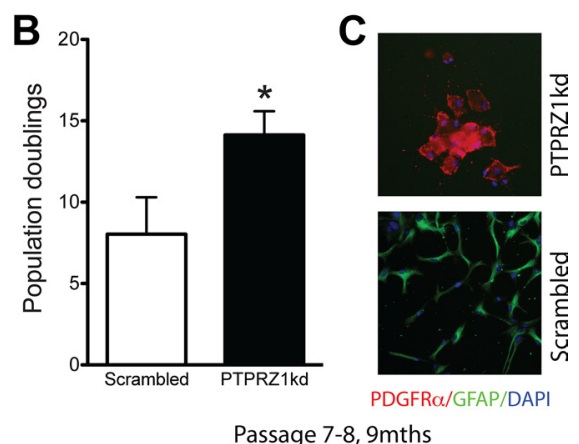

$\mathbf{F}$
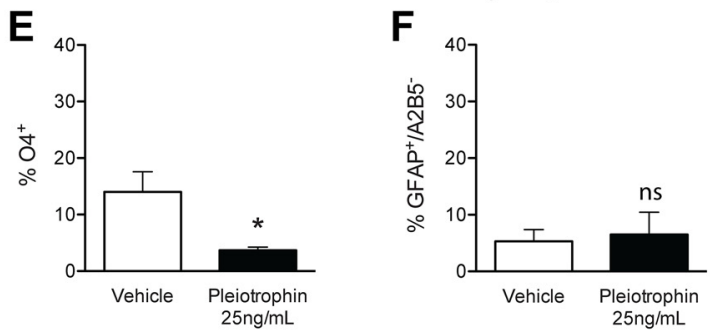

Figure 4. PTPRZ1 knockdown sustains mitotic competence and maintains the OPC phenotype. Long-term expansion of CD140a-sorted fetal hOP(s transduced with either lentiviral shRNAi directed against PTPRZ1 (PTPRZ1kd OPCs), or with a scrambled RNA control sequence (Scrambled). $\boldsymbol{A}-\boldsymbol{C}$, The PTPRZ1kd exhibited a marked increase in relative expansion, as reflected in the total

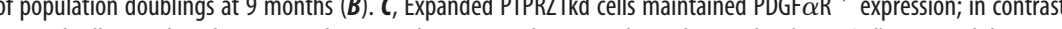
lation of $A 2 B 5^{+} / G F A P-O P C S(\boldsymbol{D})$, while decreasing oligodendrocytic maturation $(\boldsymbol{E})$. There was no change in astrocytic differentiation $(\boldsymbol{F}) .{ }^{*} p<0.05$, by Student's $t$ test $(\boldsymbol{B})$ or one-way ANOVA $(\boldsymbol{D}-\boldsymbol{F})$.

$3.6 \%$ in vehicle controls; $n=4$ ) (Fig. $4 F$ ). Similarly, the small proportion of Tuj1/ $\beta$ III-tubulin-defined neurons was not influenced by either pleiotrophin $(2.5 \pm 1.9 \%$ in pleiotrophin-treated cultures vs $2.5 \pm 2.0 \%$ in vehicle controls, $n=4$ ) or bpV(phen) $(2.3 \pm 1.9$ vs $2.0 \pm 1.4 \%, n=3$ each $)$. Together, these data confirm that both pleiotrophin and $\mathrm{bpV}$ (phen), as potent inhibitors of PTPRZ1, serve to maintain the undifferentiated phenotype of fetal human oligodendrocyte progenitor cells.

\section{Discussion}

The developmental progression and adult persistence of parenchymal OPCs reflect the ongoing balance between cellular processes favoring self-renewal and differentiation. The maintenance of both pluripotential and somatic stem cells in an undifferentiated state appears to be regulated by cytosolic accumulation and nuclear translocation of $\beta$-catenin, which leads in turn to TCF-mediated transcription of a host of genes implicated in cell cycle control that include a host of positively regulated targets of the canonical Wnt pathway (Sato et al., 2004). Accordingly, the tissue maintenance of oligodendrocyte progenitor cells, and thus the ontogeny of the oligodendroglial lineage, seems dependent upon $\mathrm{Wnt} / \beta$-catenin signaling. As such, Wnt3a-triggered signaling appears to impede oligodendrocytic maturation in the rodent brain (Shimizu et al., 2005; Feigenson et al., 2009), while the sox17-dependent suppression of $\beta$-catenin transcription, as well as that of other Wnt target genes, may promote oligodendrocytic maturation (Chew et al., 2011). Similarly, constitutive expression of a dominant-active $\beta$-catenin in OPCs delays myelination, both during development and in remyelination, by increasing the activity of the Wnt transcriptional regulators TCF3 and TCF4 (Fancy et al., 2009). Interestingly, overexpression of either dickkopfl, an extracellular Wnt inhibitor, or of a dominant-negative LEF-1 (TCF1/TCF1L7), each of which serves to suppress $\beta$-catenin-dependent signaling, both potentiate 
the production of PDGFR $\alpha^{+}$OPCs from subependymal neural progenitors (Langseth et al., 2010).

During development, cortical OPCs lose TCF reporter activity in vivo, with the exception of a perivascular subpopulation (Langseth et al., 2010); our observations suggest that this perivascular fraction of OPCs might retain greater expansion competence than parenchymally situated OPCs (Arai and Lo, 2009; Gadea et al., 2009). Importantly, following TCF activation, OPCs also upregulate expression of negative feedback genes such as Axin2, a component of the $\beta$-catenin destruction complex with GSK3 $\beta$ (Fancy et al., 2009); the secondary induction of these genes may serve to delimit the extent of mitotic expansion in response to $\beta$-catenin, whether induced by canonical Wnt signaling or otherwise. Similarly, histone deacetylase complexes directly compete with $\beta$-catenin for binding TCF, such that HDAC activity promotes both oligodendrocytic maturation and myelination (Shen et al., 2008; Ye et al., 2009; Pedre et al., 2011).

We recently reported that the myelinogenic progenitor cell pool of the fetal human cortex largely resides within the fraction of cells that may be isolated on the basis of their expression of CD140a/PDGF $\alpha$ R (Sim et al., 2011). Gene expression analysis revealed that these cells differentially expressed a number of elements of the Wnt pathway, as well as PTPRZ1 and pleiotrophin, which are similarly differentially overexpressed in adult parenchymal OPCs (Sim et al., 2006). Interestingly, PTPRZ1 is one of the top 60 genes upregulated in OPCs during murine development as well (Cahoy et al., 2008). Mice deficient in PTPRZ1 manifest no overt pathology but do exhibit overproduction of OPCs during developmental myelinogenesis (Lamprianou et al., 2011), and in adulthood they exhibit markedly impaired remyelination following experimental autoimmune encephalomyelitis (Harroch et al., 2002). Together, these observations suggest a need for PTPRZ1 in oligodendrocytic differentiation, while suggesting fundamentally different roles for PTPRZ1 in development and adulthood.

PTPRZ1 is constitutively active and is dynamically inhibited by ligand binding, which induces dimerization or oligomerization (Fukada et al., 2006) that in turn creates an inactivating steric hindrance of its phosphatase domains (Barr et al., 2009). Pleiotrophin is the most potent known natural ligand of PTPRZ1 and strongly inhibits its activity (Meng et al., 2000; Fukada et al., 2006). Importantly, besides its autocrine production by OPCs, pleiotrophin is also expressed and secreted by human brain endothelial cells (Himburg et al., 2010), suggesting a role for the perivascular niche in dictating the self-renewal competence of resident OPCs (Goldman and Chen, 2011). In addition, astrocytes and microglia have also been reported to express pleiotrophin in experimental models of ischemic injury and demyelination (Yeh et al., 1998; Fazeli et al., 2010), suggesting that the widespread inactivation of PTPRZ1 activity in response to local stressors may serve to trigger the mobilization of resident progenitors.

Pleiotrophin inhibits the constitutive tyrosine dephosphorylation of $\beta$-catenin by PTPRZ1 (Meng et al., 2000). This has the effect of regulating the nuclear availability of $\beta$-catenin, whose binding to membrane cadherins and consequent membrane sequestration is regulated by its tyrosine phosphorylation state (for review, see Gumbiner, 2005). In our studies, pleiotrophin rapidly increased the cytoplasmic appearance of $\beta$-catenin in OPCs, whereas GSK3 $\beta$ inhibition by BIO elicited its membrane accumulation with subsequent nuclear translocation. Yet, we also found that while GSK3 $\beta$ inhibition by BIO enhanced both $\beta$-catenin translocation and TCF activity, these events were independently triggered by PTPRZ1 shRNAi knockdown, and to some extent additively so, suggesting that GSK $3 \beta$ and PTPRZ1 might access different pools of $\beta$-catenin. These discrete pools of $\beta$-catenin may be functionally distinct as well; our data suggest the potential coexistence of $\beta$-catenin pools that may separately regulate cell-cell adhesion and TCF-mediated transcription, as has been noted in other systems (Kam and Quaranta, 2009).

In regards to $\beta$-catenin's transcriptional targets in OPCs, we focused on its regulation of cell cycle determinants, since fetal OPCs are enriched in Wnt target genes such as cyclin D1, which may serve to couple $\beta$-catenin signals to cell division (Sim et al., 2011). We found that pleiotrophin maintained the $\mathrm{A} 2 \mathrm{~B} 5{ }^{+}$/ $\mathrm{GFAP}^{-}$OPC population while suppressing the production of O4-defined oligodendroglia, and that PTPRZ1 knockdown was similarly associated with OPC expansion and deferred differentiation. Together, these observations suggest that the greater cytoplasmic availability of $\beta$-catenin, whether afforded by pleiotrophin inhibition of PTPRZ1 or PTPRZ1 knock-down, is sufficient to initiate the TCF-mediated activation of positive cell cycle regulators that in turn maintain the mitotic competence of human fetal OPCs.

Interestingly, whereas the inhibition of PTPRZ1 activity in fetal human OPCs potentiates their expansion while suppressing their terminal differentiation, our previous study of adult OPCs had indicated that they respond to PTPRZ1 inhibition very differently, with phenotypic differentiation toward oligodendrocytic lineage (Sim et al., 2006, 2009). In adult OPCs, PTPRZ1 thus may serve to promote the homeostatic maintenance of the progenitor state, which is effectively abrogated by PTPRZ1 inhibition. As such, PTPRZ1's function-preservation of self-renewal competence- -seems shared by both fetal and adult OPCs, but the consequences of PTPRZ1 inhibition are quite distinct in those different cellular contexts, such that PTPRZ1 inhibition in fetal OPCs leads not to terminal differentiation, but rather to dysregulated expansion. These distinct responses of fetal and adult human OPCs to PTPRZ1 inhibition likely reflect the very different cellular contexts and dominant signaling pathways of these functionally distinct phenotypes, which similarly differ in such fundamental respects as their cell cycle lengths, mitotic and migratory competence, maturation latencies, and myelination rates (Wolswijk and Noble, 1989; Windrem et al., 2004).

These data point to the signal influence of PTPRZ1 activity in establishing the effective probability of terminal differentiation by OPCs. Interestingly, our observations support the hypothesis that Wnt and tyrosine kinase signaling are diminished by receptor protein tyrosine phosphatase activity (Cummings, 2000), acting in concert with contact-mediated juxtacrine signaling, such as that effected through Notch. In that regard, it is interesting to note that pleiotrophin-modulated PTPRZ1 signaling can regulate the subcellular localization of delta/notch-1 like epidermal growth factor (DNER), suggesting that these pathways might work in concert (Fukazawa et al., 2008). In vivo, this system could be complicated by the phenotypes of neighboring cells and hence the local cellular context, which by influencing cell-cell juxtacrine signals, might yield very different signal outputs in the developing and adult brain, as well as in the setting of injury. For example, contact-dependent interactions in trans between potential axonal PTPRZ1 ligands, such as contactin, might serve to maintain the tonic activity of PTPRZ1, thus regulating the probability of OPC differentiation and oligodendrocytic maturation, and ultimately of myelination (Peles et al., 1995; Bouyain and Watkins, 2010; Lamprianou et al., 2011). Similarly, other PTPRZ1 binding partners might be important in regulating the myelination of OPC- 
derived oligodendroglia and, hence, in determining myelination efficiency, sheath thickness, and G-ratios during development.

These observations suggest that PTPRZ1 inhibition might comprise a feasible strategy by which to mobilize human OPCs while sustaining their self-renewal competence. Indeed, strategies directed at the pleiotrophin/PTPRZ1 interaction may prove effective at sustaining the remyelination potential of parenchymal oligodendrocyte progenitor cells into later stages of adulthood, as well as in response to recurrent demyelination. As such, these studies of signal control in human OPCs may provide us greater insight into a broad category of neurological diseases that share aborted remyelination and astrogliosis as key pathological events, and as previously fixed impediments to recovery.

\section{References}

Antoine M, Tag CG, Wirz W, Borkham-Kamphorst E, Sawitza I, Gressner AM, Kiefer P (2005) Upregulation of pleiotrophin expression in rat hepatic stellate cells by PDGF and hypoxia: implications for its role in experimental biliary liver fibrogenesis. Biochem Biophys Res Commun 337: 1153-1164. CrossRef Medline

Arai K, Lo EH (2009) An oligovascular niche: cerebral endothelial cells promote the survival and proliferation of oligodendrocyte precursor cells. J Neurosci 29:4351-4355. CrossRef Medline

Azim K, Butt AM (2011) GSK3beta negatively regulates oligodendrocyte differentiation and myelination in vivo. Glia 59:540-553. CrossRef Medline

Barr AJ, Ugochukwu E, Lee WH, King ONF, Filippakopoulos P, Alfano I, Savitsky P, Burgess-Brown NA, Müller S, Knapp S (2009) Large-scale structural analysis of the classical human protein tyrosine phosphatome. Cell 136:352-363. CrossRef Medline

Bouyain S, Watkins DJ (2010) The protein tyrosine phosphatases PTPRZ and PTPRG bind to distinct members of the contactin family of neural recognition molecules. Proc Natl Acad Sci U S A 107:2443-2448. CrossRef Medline

Buscarlet M, Stifani S (2007) The 'Marx' of Groucho on development and disease. Trends Cell Biol 17:353-361. CrossRef Medline

Cahoy JD, Emery B, Kaushal A, Foo LC, Zamanian JL, Christopherson KS, Xing Y, Lubischer JL, Krieg PA, Krupenko SA, Thompson WJ, Barres BA (2008) A transcriptome database for astrocytes, neurons, and oligodendrocytes: a new resource for understanding brain development and function. J Neurosci 28:264-278. CrossRef Medline

Chew LJ, Shen W, Ming X, Senatorov VV Jr., Chen HL, Cheng Y, Hong E, Knoblach S, Gallo V (2011) SRY-box containing gene 17 regulates the Wnt/beta-catenin signaling pathway in oligodendrocyte progenitor cells. J Neurosci 31:13921-13935. CrossRef Medline

Cummings FW (2000) A model of pattern formation based on signaling pathways. J Theor Biol 207:107-116. CrossRef Medline

Daniels DL, Weis WI (2005) Beta-catenin directly displaces Groucho/TLE repressors from Tcf/Lef in Wnt-mediated transcription activation. Nat Struct Mol Biol 12:364-371. CrossRef Medline

Doillon CJ, Faure RL, Posner BI, Savard PE (1999) Peroxovanadium compounds as inhibitors of angiogenesis. Angiogenesis 3:361-369. CrossRef Medline

Fancy SPJ, Baranzini SE, Zhao C, Yuk DI, Irvine KA, Kaing S, Sanai N, Franklin RJM, Rowitch DH (2009) Dysregulation of the Wnt pathway inhibits timely myelination and remyelination in the mammalian CNS. Genes Dev 23:1571-1585. CrossRef Medline

Fazeli AS, Nasrabadi D, Sanati MH, Pouya A, Ibrahim SM, Baharvand H, Salekdeh GH (2010) Proteome analysis of brain in murine experimental autoimmune encephalomyelitis. Proteomics 10:2822-2832. CrossRef Medline

Feigenson K, Reid M, See J, Crenshaw EB 3rd, Grinspan JB (2009) Wnt signaling is sufficient to perturb oligodendrocyte maturation. Mol Cell Neurosci 42:255-265. CrossRef Medline

Franklin RJ, ffrench-Constant C (2008) Remyelination in the CNS: from biology to therapy. Nat Rev Neurosci 9:839-855. CrossRef Medline

Fukada M, Fujikawa A, Chow JPH, Ikematsu S, Sakuma S, Noda M (2006) Protein tyrosine phosphatase receptor type $\mathrm{Z}$ is inactivated by ligandinduced oligomerization. FEBS Lett 580:4051-4056. CrossRef Medline

Fukazawa N, Yokoyama S, Eiraku M, Kengaku M, Maeda N (2008) Recep- tor type protein tyrosine phosphatase zeta-pleiotrophin signaling controls endocytic trafficking of DNER that regulates neuritogenesis. Mol Cell Biol 28:4494-4506. CrossRef Medline

Gadea A, Aguirre A, Haydar TF, Gallo V (2009) Endothelin-1 regulates oligodendrocyte development. J Neurosci 29:10047-10062. CrossRef Medline

Goldman SA, Chen Z (2011) Perivascular instruction of cell genesis and fate in the adult brain. Nat Neurosci 14:1382-1389. CrossRef Medline

Gordon MD, Nusse R (2006) Wnt signaling: multiple pathways, multiple receptors, and multiple transcription factors. J Biol Chem 281:22429-22433. CrossRef Medline

Gumbiner BM (2005) Regulation of cadherin-mediated adhesion in morphogenesis. Nat Rev Mol Cell Biol 6:622-634. CrossRef Medline

Harroch S, Furtado GC, Brueck W, Rosenbluth J, Lafaille J, Chao M, Buxbaum JD, Schlessinger J (2002) A critical role for the protein tyrosine phosphatase receptor type $\mathrm{Z}$ in functional recovery from demyelinating lesions. Nat Genet 32:411-414. CrossRef Medline

Himburg HA, Muramoto GG, Daher P, Meadows SK, Russell JL, Doan P, Chi JT, Salter AB, Lento WE, Reya T, Chao NJ, Chute JP (2010) Pleiotrophin regulates the expansion and regeneration of hematopoietic stem cells. Nat Med 16:475-482. CrossRef Medline

Kam Y, Quaranta V (2009) Cadherin-bound beta-catenin feeds into the Wnt pathway upon adherens junctions dissociation: evidence for an intersection between beta-catenin pools. PLoS ONE 4:e4580. CrossRef Medline

Korinek V, Barker N, Morin PJ, van Wichen D, de Weger R, Kinzler KW, Vogelstein B, Clevers H (1997) Constitutive transcriptional activation by a beta-catenin-Tcf complex in $\mathrm{APC}^{-1-}$ colon carcinoma. Science 275 : 1784-1787. CrossRef Medline

Lamprianou S, Chatzopoulou E, Thomas JL, Bouyain S, Harroch S (2011) A complex between contactin-1 and the protein tyrosine phosphatase PTPRZ controls the development of oligodendrocyte precursor cells. Proc Natl Acad Sci U S A 108:17498-17503. CrossRef Medline

Langseth AJ, Munji RN, Choe Y, Huynh T, Pozniak CD, Pleasure SJ (2010) Wnts influence the timing and efficiency of oligodendrocyte precursor cell generation in the telencephalon. J Neurosci 30:13367-13372. CrossRef Medline

Meijer L, Skaltsounis AL, Magiatis P, Polychronopoulos P, Knockaert M, Leost M, Ryan XP, Vonica CA, Brivanlou A, Dajani R, Crovace C, Tarricone C, Musacchio A, Roe SM, Pearl L, Greengard P (2003) GSK-3selective inhibitors derived from Tyrian purple indirubins. Chem Biol 10:1255-1266. CrossRef Medline

Meng K, Rodriguez-Pena A, Dimitrov T, Chen W, Yamin M, Noda M, Deuel TF (2000) Pleiotrophin signals increased tyrosine phosphorylation of beta beta-catenin through inactivation of the intrinsic catalytic activity of the receptor-type protein tyrosine phosphatase beta/zeta. Proc Natl Acad Sci U S A 97:2603-2608. CrossRef Medline

Nelson WJ, Nusse R (2004) Convergence of Wnt, beta-catenin, and cadherin pathways Science 303:1483-1487. CrossRef

Pedre X, Mastronardi F, Bruck W, López-Rodas G, Kuhlmann T, Casaccia P (2011) Changed histone acetylation patterns in normal-appearing white matter and early multiple sclerosis lesions. J Neurosci 31:3435-3445. CrossRef Medline

Peifer M, Sweeton D, Casey M, Wieschaus E (1994) wingless signal and Zeste-white 3 kinase trigger opposing changes in the intracellular distribution of Armadillo. Development 120:369-380. Medline

Peles E, Nativ M, Campbell PL, Sakurai T, Martinez R, Lev S, Clary DO, Schilling J, Barnea G, Plowman GD, Grumet M, Schlessinger J (1995) The carbonic anhydrase domain of receptor tyrosine phosphatase beta is a functional ligand for the axonal cell recognition molecule contactin. Cell 82:251-260. CrossRef Medline

Posner BI, Faure R, Burgess JW, Bevan AP, Lachance D, Zhang-Sun G, Fantus IG, Ng JB, Hall DA, Lum BS (1994) Peroxovanadium compounds. A new class of potent phosphotyrosine phosphatase inhibitors which are insulin mimetics. J Biol Chem 269:4596-4604. Medline

Rosenkranz S, DeMali KA, Gelderloos JA, Bazenet C, Kazlauskas A (1999) Identification of the receptor-associated signaling enzymes that are required for platelet-derived growth factor-AA-dependent chemotaxis and DNA synthesis. J Biol Chem 274:28335-28343. CrossRef Medline

Roy NS, Wang S, Harrison-Restelli C, Benraiss A, Fraser RA, Gravel M, Braun PE, Goldman SA (1999) Identification, isolation, and promoter-defined 
separation of mitotic oligodendrocyte progenitor cells from the adult human subcortical white matter. J Neurosci 19:9986-9995. Medline

Roy NS, Nakano T, Keyoung HM, Windrem M, Rashbaum WK, Alonso ML, Kang J, Peng W, Carpenter MK, Lin J, Nedergaard M, Goldman SA (2004) Telomerase immortalization of neuronally restricted progenitor cells derived from the human fetal spinal cord. Nat Biotechnol 22:297-305. CrossRef Medline

Sato N, Meijer L, Skaltsounis L, Greengard P, Brivanlou AH (2004) Maintenance of pluripotency in human and mouse embryonic stem cells through activation of Wnt signaling by a pharmacological GSK-3-specific inhibitor. Nat Med 10:55-63. CrossRef Medline

Scolding NJ, Rayner PJ, Compston DA (1999) Identification of A2B5positive putative oligodendrocyte progenitor cells and A2B5-positive astrocytes in adult human white matter. Neuroscience 89:1-4. CrossRef Medline

Shen S, Sandoval J, Swiss VA, Li J, Dupree J, Franklin RJM, Casaccia-Bonnefil P (2008) Age-dependent epigenetic control of differentiation inhibitors is critical for remyelination efficiency. Nat Neurosci 11:1024-1034. CrossRef Medline

Shimizu T, Kagawa T, Wada T, Muroyama Y, Takada S, Ikenaka K (2005) Wnt signaling controls the timing of oligodendrocyte development in the spinal cord. Dev Biol 282:397-410. CrossRef Medline

Sim FJ, Windrem MS, Goldman SA (2009) Fate determination of adult human glial progenitor cells. Neuron Glia Biol 5:45-55. CrossRef Medline

Sim FJ, McClain CR, Schanz SJ, Protack TL, Windrem MS, Goldman SA (2011) CD140a identifies a population of highly myelinogenic, migration-competent and efficiently engrafting human oligodendrocyte progenitor cells. Nat Biotechnol 29:934-941. CrossRef Medline

Sim FJ, Lang JK, Waldau B, Roy NS, Schwartz TE, Pilcher WH, Chandross KJ, Natesan S, Merrill JE, Goldman SA (2006) Complementary patterns of gene expression by adult human oligodendrocyte progenitor cells and their white matter environment. Ann Neurol 59:763-779. CrossRef Medline

van Amerongen R, Nusse R (2009) Towards an integrated view of Wnt signaling in development. Development 136:3205-3214. CrossRef Medline

Windrem MS, Roy NS, Wang J, Nunes M, Benraiss A, Goodman R, McKhann GM 2nd, Goldman SA (2002) Progenitor cells derived from the adult human subcortical white matter disperse and differentiate as oligodendrocytes within demyelinated lesions of the rat brain. J Neurosci Res 69:966-975. CrossRef Medline

Windrem MS, Nunes MC, Rashbaum WK, Schwartz TH, Goodman RA, McKhann G 2nd, Roy NS, Goldman SA (2004) Fetal and adult human oligodendrocyte progenitor cell isolates myelinate the congenitally dysmyelinated brain. Nat Med 10:93-97. CrossRef Medline

Windrem MS, Schanz SJ, Guo M, Tian GF, Washco V, Stanwood N, Rasband M, Roy NS, Nedergaard M, Havton LA, Wang S, Goldman SA (2008) Neonatal chimerization with human glial progenitor cells can both remyelinate and rescue the otherwise lethally hypomyelinated shiverer mouse. Cell Stem Cell 2:553-565. CrossRef Medline

Wolswijk G, Noble M (1989) Identification of an adult-specific glial progenitor cell. Development 105:387-400. Medline

Ye F, Chen Y, Hoang T, Montgomery RL, Zhao XH, Bu H, Hu T, Taketo MM, van Es JH, Clevers H, Hsieh J, Bassel-Duby R, Olson EN, Lu QR (2009) $\mathrm{HDAC} 1$ and HDAC2 regulate oligodendrocyte differentiation by disrupting the $\beta$-catenin-TCF interaction. Nat Neurosci 12:829-838. CrossRef Medline

Yeh HJ, He YY, Xu J, Hsu CY, Deuel TF (1998) Upregulation of pleiotrophin gene expression in developing microvasculature, macrophages, and astrocytes after acute ischemic brain injury. J Neurosci 18:3699-3707. Medline 